\title{
Business Ethics in Providing Financial Statements: The Testing of Fraud Pentagon Theory on the Manufacturing Sector in Indonesia
}

http://doi.org/10.21272/bel.3(3).68-77.2019

\section{Einde Evana}

$\mathrm{PhD}$, Senior Lecture, Accounting Department, Economics and Business Faculty, University of Lampung, Indonesia

\section{Mega Metalia}

MSc, Lecture, Accounting Department, Economics and Business Faculty, University of Lampung, Indonesia

\section{Edwin Mirfazli}

PgC MPhil (Hons), Senior Researcher, Accounting Department, Economics and Business Faculty, University of Lampung, Indonesia

\section{Daniela Ventsislavova Georgieva}

PhD, Assistant Professor, Business Faculty, International Business School, Bulgaria

\section{Istianingsih Sastrodiharjo}

$\mathrm{PhD}$, Senior Lecture, Accounting Department, Business Faculty, Indonesian Banking School, Jakarta, Indonesia

\begin{abstract}
The article studies the causes and consequences of manipulating the financial statements of companies, identifies the most influential drivers of fraudulent reporting actions by employees and business owners. This research aimed to examine the effect of fraud indicators in fraud pentagon theory against the detection of fraudulent financial reporting on manufacturing companies. Independent variables in this research were variable pressure proxy by financial stability, external pressure, and financial target, opportunity proxy by nature of the industry, rationalization proxy by total accrual, capability proxy by the change of directors, and arrogance proxy by ownership by management. The dependent variable was the fraudulent financial reporting proxy by fraud score. The sample of this research used 57 manufacturing companies listed on the Indonesia Stock Exchange Effect in 2013-2015. It is found that the result of the determination coefficient test shows an adjusted $\mathrm{R} 2$ value of 0.068 , it means that the ability of the independent variable in explaining the variants of the dependent variable is still limited, which is $6.8 \%$. The ANOVA test, which shows the possibility of using the regression model to predict the Fraudulent Financial Report, serves as the methodological tool of the study. It is determined that pressure with proxies of financial stability (current), external pressure (Lev), and financial target (ROA), opportunity with the nature of industry (receivable) proxy, and arrogance with managerial ownership (OM) proxy do not affect fraudulent financial reporting. The result of this research showed that rationalization variables proxy by the total accrual ratio and capability proxy by the change of directors had an influence on the fraudulent financial reporting. While the pressure variable proxy by financial stability measured with the current ratio, external pressure measured with leverage ratio, financial target measured with ROA, opportunity variable proxy by nature of industry variable measured with the change in inventory ratio, and arrogance proxy by ownership by management had no influence on financial statement fraud. The results obtained can be useful both for the management of the company and for regulatory authorities in terms of understanding the growth indicators of the financial statement fraud frequency and tools to minimize their impact.
\end{abstract}

Keywords: fraud, fraud pentagon, fraudulent financial reporting, financial statement fraud, leverage ratio, managerial ownership and manufacturing sector.

JEL Classification: D18, D70, D73, G32, K40.

Cite as: Evana, E., Metalia, M., Mirfazli, E., Georgieva, D.V., Sastrodiharjo, I. (2019). Business Ethics in Providing Financial Statements: The Testing of Fraud Pentagon Theory on the Manufacturing Sector in Indonesia. Business Ethics and Leadership, 3(3), 68-77. http://doi.org/10.21272/bel.3(3).68-77.2019.

(C) The Authors, 2019. This article is published with open access at Sumy State University. 


\section{Introduction}

Financial report publishing generally aims to give information on the financial position, performance, and cash flow of the company. However, there is still fraudulent practice on the financial reporting so that the company is valued good. Fraudulent financial reporting is a problem that cannot be underestimated, wherein 2016, Fraudulent Financial Reporting became 9.6\% compared to the one in 2014 was only 9.0\% (ACFE, 2016). It affects the information needed by stakeholders in decision making to be irrelevant and unreliable.

Based on the survey conducted by the Association of Certified Fraud Examiner (ACFE) in 2016, it shows the fact that the manufacturing sector in an industry that conducts many frauds. It is because, in the manufacturing industry, the company conducts production process starting from raw materials to finished goods that certainly has many fraudulent actions such as supply. Moreover, there is an uncollectible account that is a form of estimation that is the cause of fraud vulnerability on financial reporting in manufacturing the industry.

Generally, fraud will always occur when there is no prevention and detection previously. Therefore, there are some ways in detecting fraud such as fraud triangle, fraud diamond, and fraud pentagon. In this study, the writer uses Crowe's fraud pentagon theory in detecting the presence of fraud in financial reporting. It is done because the theory is rarely applied in the study of fraudulent financial reporting, and the fraud indicator described in Crowe's fraud pentagon theory is more complete compared to similar theories such as fraud triangle theory and fraud diamond theory.

Based on the above background, this study is done to conduct the testing again on fraudulent financial reporting by using fraud pentagon on the manufacturing sector. Therefore, this study replicates the study from Tessa (2016) aiming to conduct more comprehensive testing on the ability of Crowe's fraud pentagon theory proposed by Crowe (2010), to investigate and give further explanation whether Crowe's fraud pentagon theory can help detecting the presence of fraudulent financial reporting tendency especially on financial and banking sector in Indonesia.

The difference of this study to the previous study is that on the number of proxies on variables of financial stability, external pressure, financial target, nature of the industry, total accruals, change of directors, and ownership by management. Meanwhile, the sample used in this study is manufacturing companies listed on IDX in 2013-2015. Moreover, this study is done to investigate factors that have not been consistent from the previous studies to affect someone in conducting fraud in pentagon theory.

\section{Theoretical Framework and Hypothesis Development}

\section{Agency Theory}

Agency theory according to Jensen and Meckling (1976):

“...an agency relationship as a contract under which one or more persons (the principal(s)) engage another person (the agent) to perform some service on their behalf which involves delegating some decision making authority to the agent".

It means, "agency relationship as a contract under which one or more persons (the principal(s)) engage another person (the agent) to perform some service on their behalf which involves delegating some decision making to the agent".

However, in its practice, the relationship often has information asymmetry that creates the presence of interest conflict between principal and agent which is capital owners and capital managers or corporate management that is known as conflict of interest. Conflict of interest occurs because there is interest difference, where the principal wants an agent to conduct something as what he/she wants, while the agent wants to conduct something for maximizing his/her utility (Rini, 2012). Therefore, with the presence of asymmetry between the management (agent) and the owner (principal), it gives the opportunity to the manager to conduct earnings management in order to maximize his/her utility. 


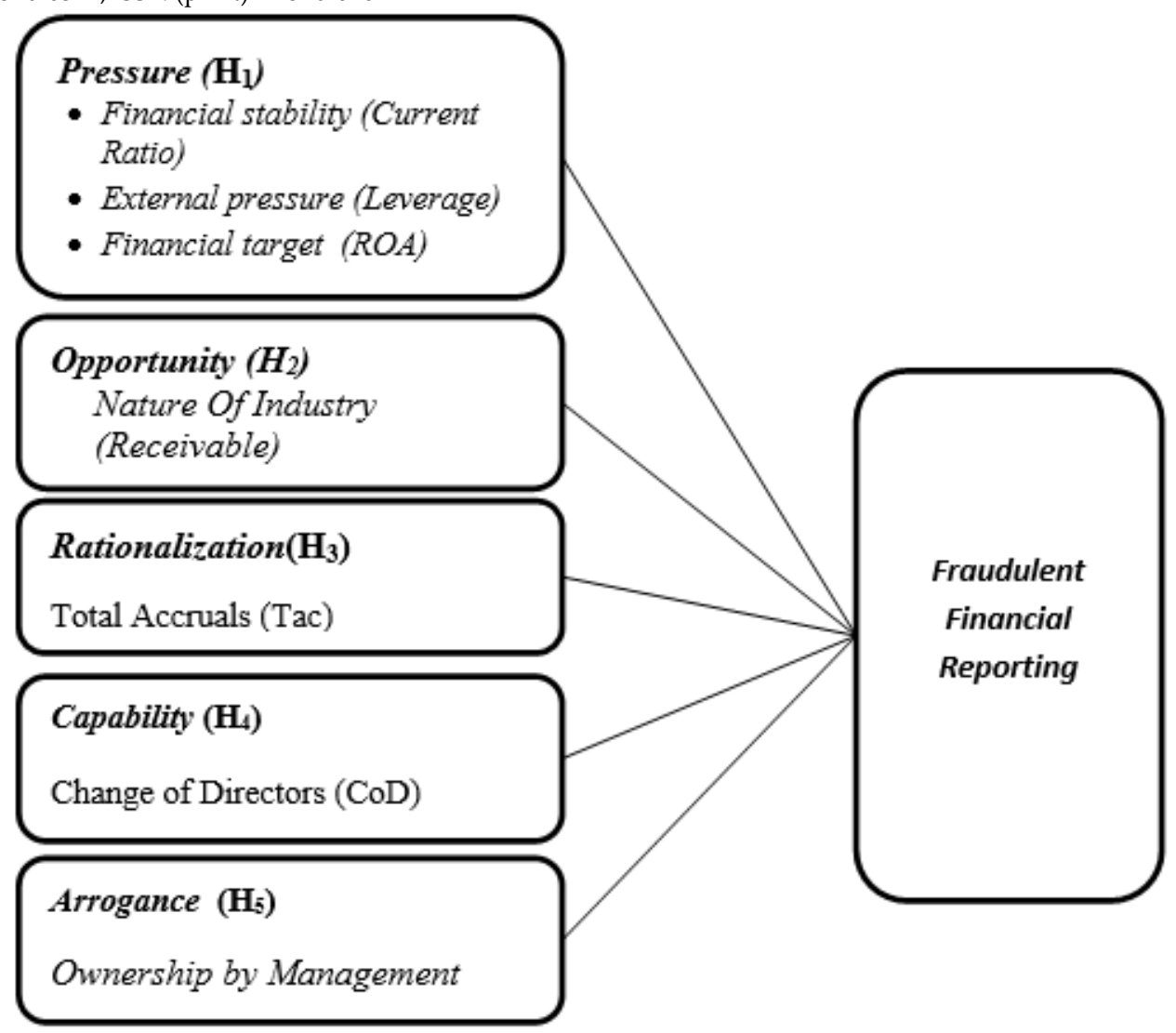

Figure 1. Research Framework

Source: Develop by researchers

\section{The Effect of Pressure on Fraudulent Financial Reporting}

The pressure is a condition when someone conducts fraud because of the presence of pressure. In this study, the writer uses the proxy from 3 kinds of general conditions (financial stability, external pressure, and financial targets) as the following:

\section{Financial Stability}

According to Munawir (2014) to investigate business stability, it can be measured by considering the ability of the company to pay interest expense on its debts including repaying its main debt on time as well as the ability to pay dividends regularly to shareholders without having obstacles or financial crisis. Therefore, in this study, the writer uses the current ratio to proxy stability pressure. In the studies from Manurung and Hadian (2013), Sihombing and Rahardjo (2014), as well as Tessa (2016), financial stability affects the possibility of fraudulent financial reporting by using assets change (ACHANGE).

\section{External Pressure}

External pressure is a condition where a company receives pressure from external parties of the company. External pressure is proxied by using leverage ratio (LEV). If a company has high leverage, it means that the company is considered having a large debt and high credit risk. The higher credit risk, the greater the concern level of the creditor to give s to the company. The study done by Pardosi (2015) proved that external pressure does not affect fraud. Meanwhile, the studies conducted by Sihombing and Rahardjo (2014) and Tessa (2016) stated that external pressure has an impact on detecting fraudulent financial reporting. Therefore, the writer uses leverage ratio (LEV) as the proxy from external pressure.

\section{Financial Target}

There is excessive pressure on management or personal operation to fulfill financial targets established by the responsible party on governance or management, including sales or probability incentive goals. Corporate financial target generally is in the form of business earnings that can be projected on Return on Assets (ROA) in financial reporting. The study of Sihombing and Rahardjo (2014) did not strengthen the evidence that return on assets (ROA) affects financial statement fraud. This result is supported by the studies 
from Tessa (2016) and Annisya (2016) stating that the variable of financial target proxied by ROA does not affect financial statement fraud.

Pressures from the principal addressed to the manager in order to get a target that is wanted to be achieved push the agent to conduct any actions in order to show that the company is in good condition rather than the real condition. In other words, management conducts fraudulent action.

Based on the explanation, the hypothesis proposed is:

$\mathrm{H}_{1}$ : Pressure affects fraudulent financial reporting.

\section{The Effect of Opportunity on Fraudulent Financial Statement}

Opportunity is a condition where someone conducts fraudulent action caused by the presence of opportunity. In this study, the opportunity is projected by Nature of Industry that is related to the presence of risk involving significant estimation and consideration that are far bigger. The study of Ardiyani and Utaminingsih (2015) stated that the variable of nature of the industry with inventory proxy does not have an effect on financial statement fraud. Meanwhile, the study of Sihombing and Rahardjo (2014) stated that the nature of industry proxied by receivable positively affects fraudulent financial reporting. Based on the previous study, the writer uses a proxy for the nature of industry related to the ratio of changing in business receivable. Based on the description, the hypothesis that can be taken is:

\section{$\mathrm{H}_{2}$ : Opportunity affects fraudulent financial reporting.}

\section{The Effect of Rationalization on Fraudulent Financial Reporting}

Rationalization is the presence of attitude, characteristic, or a series of ethical values that allow certain parties to conduct fraudulent action. According to Jones (2018), the variable of total accrual ratio can be used to describe rationalization related to the use of the accrual principle by management. Total accrual is all accruals appearing in one period of time. Total accrual is calculated as current asset change minus cash change, minus current obligation change plus short-term debt change minus depreciation cost and amortization minus deferred income tax plus capital. Based on the statement, the hypothesis that can be concluded is:

$\mathrm{H}_{3}$ : Rationalization affects fraudulent financial reporting.

\section{The Effect of Capability on Fraudulent Financial Statement}

Capability owned by someone in a company will affect the possibility of someone to conduct fraud. This study will use the change of directors as capability proxy. The change of directors can be an effort of the company to improve the performance of previous directors. However, the presence of directors' change needs the time of adaption toward a new culture in order to reduce effectiveness in performance. It will cause a stress period that affects more opened opportunities to conduct fraud (Wolfe and Hermanson, 2004). Sihombing and Rahardjo (2014), Pardosi (2015) and Tessa (2016) used the change of directors as a proxy from the capability to investigate indication of fraudulent financial statement occurrence. Based on the explanation, this study proposes the hypothesis as the following:

$\mathrm{H}_{4}$ : Capability affects a fraudulent financial statement.

\section{The Effect of Arrogance on fraudulent financial reporting}

Managerial owner is a situation where a manager has corporate shares or in other words that the manager is also a shareholder (Karima, 2014). With the presence of some shares owned by corporate management, it will affect the policy of management made in disclosing corporate financial performance. It can cause an arrogance attitude where the management feels that any internal control will not be applied to them because of the status and position they have. The study done by Tiffani dan Marfuah (2015) shows that the percentage of shareholding by inside persons (OSHIP) does not affect fraudulent financial reporting. Based on the explanation, research hypothesis proposed is:

$\mathrm{H}_{5:}$ Arrogance affects fraudulent financial reporting.

\section{Research Method}

\section{Population and Sample}

The population in this study is all go public companies listed on the Indonesia Stock Exchange. The sampling method uses a purposive sampling method which is a sampling-based on the purpose of the study with special considerations. The criteria in sampling are: 
ISSN (online) - 2520-6311; ISSN (print) - 2520-6761

1. Manufacturing companies that have been gone public or listed on the Indonesia Stock Exchange (IDX) during the period of 2013-2015.

2. Companies published annual financial reports that had been audited on companies' websites of the IDX website during the period 2013-2015 that is stated in Rupiah (Rp).

3. Companies that had profit during the period 2013-2015.

4. Companies were not delisted during the period 2013-2015.

5. Data on the data related to research variables are completely available (data were entirely available on the publication during the period 2013-2015).

Dependent and Independent Variables

Table 1. Variable Measurement

\begin{tabular}{|c|c|c|}
\hline Variable & Proxy & Measurement \\
\hline $\begin{array}{l}\text { Fraudulent } \\
\text { Financial Reporting }\end{array}$ & Fraud Score (F-Score) & F-Score $=$ Accrual Quality + Financial Performance \\
\hline \multirow{3}{*}{ Pressure } & $\begin{array}{l}\text { Financial Stability } \\
(\text { Current Ratio })\end{array}$ & Current Ratio $=\frac{\text { Aset Lancar }}{\text { Utang Lancar }}$ \\
\hline & $\begin{array}{l}\text { External } \\
\text { (Leverage) }\end{array}$ & $L E V=\frac{\text { Total Liabilitas }}{\text { Total Aset }}$ \\
\hline & Financial Target (ROA) & $R O A=\frac{\text { Earning After Interest and Tax }}{\text { Total Asset } t}$ \\
\hline Opportunity & $\begin{array}{l}\text { Nature of industry } \\
\text { (Receivable) }\end{array}$ & Receivable $=\frac{\text { Receivable }_{t}}{\text { Sales }_{t}}-\frac{\text { Receivable }_{t-1}}{\text { Sales }_{t-1}}$ \\
\hline Rationalization & Total Accruals (TAc) & $T A c=\frac{\begin{array}{c}\Delta \text { working capital }-\Delta \text { cash }-\Delta \text { current tax payable }- \\
\text { depereciation and amortization }\end{array}}{\text { Total Asset }}$ \\
\hline Capability & $\begin{array}{l}\text { Change of Directors } \\
(\mathrm{CoD})\end{array}$ & $\begin{array}{l}\text { Dummy variable, where } 1=\text { there is a change of directors during observation } \\
\text { year, and } 0=\text { there is no change of directors. }\end{array}$ \\
\hline Arrogance & $\begin{array}{l}\text { Managerial } \\
\text { Shareholding }(\mathrm{OM})\end{array}$ & $\begin{array}{l}\text { Dummy variable, where } 1=\text { there is managerial ownership during observation } \\
\text { year, and } 0=\text { there is no managerial shareholding. }\end{array}$ \\
\hline
\end{tabular}

Source: Various Supporting Literatures, 2016

\section{Data Analysis Method}

Hypothesis testing is done with multiple regression analysis using regression equation as the following:

$$
\begin{aligned}
& \text { F SCORE }=ß 0+ß 1 \text { Current Ratio }+ \text { BLEV + ß3ROA + ß4Receiveble + ß5TAc + ß6CoD } \\
& +\beta 70 M+\varepsilon
\end{aligned}
$$

Information:

F-Score

ß0

$\beta 1,2,3,4,5,6,7$

Current Ratio

LEV

ROA

Receivable

TAc

CoD

$\mathrm{OM}$

$\varepsilon$
= Fraudulent Financial Statement;

$=$ Constant;

$=$ Regression coefficient of each proxy;

$=$ Current asset ratio per total short-term obligations;

$=$ Total ratio of obligation per total assets;

= Return on Assets;

$=$ Ratio of accounts receivable during 2013-2015;

$=$ Total accruals;

$=$ Change of directors in company;

= Shareholding by management;

= error. 


\section{Result and Discussion}

The population of this study is all companies listed on the Indonesia Stock Exchange. The sample of this study is manufacturing companies in 2013-2015. Based on the data obtained, there are 135 manufacturing companies that have been gone public during the period of 2013-2015 and 59 companies that fulfill the criteria as the sample of the study. The observation period in this study is 3 years, so the total sample in this study is 177 annual financial reports. In this study, there are outlier data as many as 20 observations, so the number of all samples is 157 observations.

\section{Data Analysis}

\section{Descriptive Statistics}

Descriptive statistics gives an illustration or description of data that are seen from the average value (mean), standard deviation, variants, maximum, minimum, sum, range, kurtosis, and skewness (distribution skewness) of each variable (Ghozali, 2013). In this study, the descriptive statistics of testing done gives the result as the following:

Table 2. The Testing Result of Descriptive Statistics

Descriptive Statistics

\begin{tabular}{|l|c|c|c|c|c|}
\hline & $\mathbf{N}$ & Minimum & Maximum & Mean & Std. Deviation \\
\hline F-SCORE & 157 & -.80 & .89 & .0921 & .29075 \\
Sqr CURRENT & 157 & .04 & 65.43 & 6.7868 & 9.10019 \\
Sqr LEV & 157 & .02 & .53 & .1883 & .12373 \\
Sqr ROA & 157 & .00 & .06 & .0091 & .01159 \\
Sqr RECEIVABLE & 157 & .00 & .02 & .0008 & .00201 \\
Sqr TAc & 157 & .00 & .06 & .0067 & .01184 \\
CoD & 157 & 0 & 1 & .40 & .492 \\
OM & 157 & 0 & 1 & .50 & .502 \\
Valid N (listwise) & 157 & & & & \\
\hline
\end{tabular}

Source: Processed data with SPSS

Based on the descriptive statistics output in Table 2, it is explained that:

1. Variable Fraudulent Financial Reporting proxied with F-Score has a value of 0.0921, meaning that the risk level of fraud occurring in manufacturing sector is relatively low which is $9.21 \%$. The standard deviation value resulted is 0.29075 , meaning that there are some companies in the manufacturing sector that have the risk of fraud that deviates too high or too low which is $29 \%$. Then, the minimum and maximum values are -0.80 and 0.989 .

2. Variable pressure with Financial Stability proxy that is proxied again with the Current ratio has a maximum value from Current is 65.43 from company Lionmesh Prima Tbk in 2015. The minimum value obtained is 0.04 on the company Selamat Sempurna Tbk in 2015. The value of firm size is 6.7868 and the standard deviation is 9.10019 .

3. Variable pressure with external pressure proxy in this study that is proxied with leverage has a maximum value obtained of 0.53 by the company Jembo Cable Company Tbk in 2015 and a minimum value of 0.02 from the company Indocement Tunggal Prakasa in 2013. The mean value of the variable net profit margin is 0.1883 and the standard deviation is 0.12373 .

4. Variable pressure with Financial Target proxy in this study that is proxied with Return on Asset (ROA) has a maximum value of 0.06 that is obtained from the company Selamat Sempurna Tbk in 2014 and a minimum value of 0.00 on the company Indospring Tbk in 2015. The mean value on the variable ROA is 0.0091 with the standard deviation of 0.01159 .

5. Variable Opportunity with the nature of industry proxy in this study that is proxied with receivable has a maximum value of 0.02 that is obtained from the company Ricky Putra Globalindo Tbk in 2013 and a minimum value of 0.00 on the company Mandom Indonesia Tbk in 2013. The mean value from the variable Receivable is 0.0008 and the standard deviation obtained is 0.00201 .

6. Variable rationalization with total accruals proxy results in a maximum value of 0.06 on the company Wismilak Inti Makmur Tbk in 2013 and a minimum value of 0.00 in the company Indofood CBP Sukses Makmur Tbk in 2013. The mean value obtained based on Table 2 above is 0.0067 with the standard deviation of 0.01184 . 
ISSN (online) - 2520-6311; ISSN (print) - 2520-6761

7. Variable capability that is proxied with the change of directors $(\mathrm{CoD})$ is a dummy variable, where if there is a change of directors during observation year, it is given score 1 and if there is no change of directors, it is given score 0 . Thus, CoD obtains a maximum value of 1 and a minimum value of 0 , with the mean value obtained by the variable of 0.40 with the standard deviation of 0.492 .

8. Variable arrogance that is proxied with managerial shareholding $(\mathrm{OM})$ is a dummy variable. If there is managerial shareholding during the observation year, it is given score 1 , and if there is no managerial shareholding, it is given score 0 , with the mean value obtained by the variable of 0.50 with the standard deviation of 0.502 .

This study has passed the classic assumption tests which are normality, multicollinearity, autocorrelation, and heteroscedasticity tests. Next, it is found that the result of the determination coefficient test shows an adjusted $\mathrm{R} 2$ value of 0.068 , it means that the ability of the independent variable in explaining the variants of the dependent variable is still limited, which is $6.8 \%$. There are $93.2 \%$ of other factors that can affect FScore that cannot be explained by independent variables in this study. Based on the ANOVA test or F test, it shows $F$ value of 2.629 with the significance of 0.014 . Significance value that is smaller than 0.05 shows that the regression model can be used to predict Fraudulent Financial Reporting, or it can be said that all independent variables together affect dependent variables.

\section{Hypothesis Testing}

Table 3. Hypothesis

Coefficients $^{\mathrm{a}}$

\begin{tabular}{|c|c|c|c|c|c|}
\hline \multirow[b]{2}{*}{ Model } & \multicolumn{2}{|c|}{ Unstandardized Coefficients } & \multirow{2}{*}{$\begin{array}{c}\text { Standardized Coefficients } \\
\text { Beta } \\
\end{array}$} & \multirow[b]{2}{*}{$\mathbf{t}$} & \multirow[b]{2}{*}{ Sig. } \\
\hline & B & Std. Error & & & \\
\hline 1 (Constant) & .216 & .080 & & 2.712 & .007 \\
\hline Sqr CURRENT & -.006 & .003 & -.176 & -1.873 & .063 \\
\hline Sqr LEV & -.364 & .241 & -.155 & -1.510 & .133 \\
\hline Sqr ROA & 3.774 & 2.217 & .150 & 1.702 & .091 \\
\hline Sqr RECEIVABLE & -1.515 & 11.640 & -.010 & -.130 & .897 \\
\hline Sqr TAc & -3.888 & 1.921 & -.158 & -2.023 & .045 \\
\hline CoD & -.127 & .047 & -.216 & -2.688 & .008 \\
\hline $\mathrm{OM}$ & .052 & .046 & .090 & 1.137 & .257 \\
\hline
\end{tabular}

a. Dependent Variable: F-SCORE

Source: Processed Data in SPSS 22

Based on the table above, it is found that variable rationalization with total accruals and capability proxy with change of directors proxy have significance value $<0.05$, which are 0.045 and 0,008 as well as $\mathrm{t}$-statistic value of -0.023 and $-2.688>$ the value of t-table of 1.97591 , so rationalization and capability affect fraudulent financial reporting. Next, variable pressure with the proxy of current, leverage, and ROA, variable opportunity with nature of industry proxy, as well as variable arrogance with managerial shareholding have significance value $>0.05$, so they do not affect fraudulent financial statement.

\section{The Effect of Pressure on Fraudulent Financial Reporting}

\section{Financial Stability}

The testing result of hypothesis $1\left(\mathrm{H}_{1}\right)$ with financial stability (current) proxy does not significantly affect in detecting fraudulent financial reporting with the significance level of 0.063 and B -0.006 . Based on the testing result, it does not prove that the lower ability of the company in paying its short-term debt can push the company to conduct fraudulent financial reporting. It does not support the studies that have been done by Sihombing and Rahardjo (2014), Hanifa and Laksito (2015), as well as Tessa (2016) that financial stability affects the possibility of fraudulent financial reporting occurrence.

\section{External Pressure}

The testing result of hypothesis $1\left(\mathrm{H}_{1}\right)$ with external pressure proxy shows that external pressure (LEV) does not significantly affect fraudulent financial reporting with the significance level of 0.133 and $\mathrm{B}-0.364$. The testing result does not prove that the higher leverage, the bigger the possibility to conduct violations against credit agreement through fraudulent financial reporting. The result is in accordance with the study that has been done by Manurung and Hadian (2013) proving that external pressure does not affect fraudulent financial reporting. However, it does not support the studies of Sihombing (2014) and Tessa (2016) stating that external pressure significantly affects fraudulent financial reporting. 


\section{Financial Target}

The testing result of hypothesis $1\left(\mathrm{H}_{1}\right)$ with financial target proxy stated that financial target (ROA) does not significantly affect the possibility of fraudulent financial reporting with the significance level of 0.091 and B 3.774. It means the big or small targeted ROA by the company does not affect management to conduct fraudulent financial reporting. The result of this study supports the studies done by Sihombing (2014) and Tessa (2016) stating that there is no effect between financial targets on the possibility of fraudulent financial reporting occurrence. The absence of ROA effect on fraudulent financial reporting in this study might be because the manager assumes that the size of the company's ROA target is still considered normal and can be achieved. The manager does not consider that the ROA target as a financial target that is difficult to be achieved, so the ROA target does not trigger the occurrence of fraudulent financial reporting done by the manager.

\section{The Effect of Opportunity on Fraudulent Financial Reporting}

The testing of the second hypothesis $\left(\mathrm{H}_{2}\right)$ with the nature of industry (receivable) proxy shows the value of B of -1.515 with the significance of 0.897 , it can be concluded that the nature of industry does not significantly affect fraudulent financial reporting. It means that the hypothesis is rejected because the mean value of corporate receivable from the previous year does not affect corporate cash flow. Therefore, the study result is in accordance with the study done by Tiffani and Marfuah (2015) stating that the variable nature of industry does not significantly affect financial statement fraud. However, the result contradicts with the study done by Sihombing and Raharjo (2014) stating that the nature of industry affects significantly.

\section{The Effect of Rationalization on Fraudulent Financial Reporting}

The testing of the third hypothesis $\left(\mathrm{H}_{3}\right)$ shows that rationalization with total accruals proxy has $B$ value of -3.888 with the significance of 0.045 , it can be concluded that rationalization significantly affects fraudulent financial reporting. It shows that the alternative hypothesis $\left(\mathrm{H}_{3}\right)$ is accepted. The level of corporate accruals will depend on the decision of management related to a certain policy. This study is consistent with the study done by Sihombing and Rahardjo (2014) stating that total accruals affect fraudulent financial reporting.

\section{The Effect of Capability on Fraudulent Financial Statement}

The testing result of the fourth hypothesis $\left(\mathrm{H}_{4}\right)$ shows that variable capability with change of directors $(\mathrm{CoD})$ proxy significantly affects in detecting fraudulent financial reporting with a significance level of 0.008 and B -0.127. The result of the testing done is in accordance with the study that has been done by Pardosi (2015) stating that a change of directors affects fraudulent financial reporting. However, it contradicts with the studies done by Sihombing (2014) as well as Hanifa and Laksito (2015) concluding that the change of directors of the company does not affect in detecting fraudulent financial reporting.

It might be because the change of directors' proxy does not always affect well for the company. The change of directors can be an effort of the company to improve the previous directors' performance by conducting board of directors change or recruitment of new directors that are considered more competent compared to the previous directors. Meanwhile, on the other side, the change of directors can be an effort of the company to eliminate directors that are considered to know fraud that is done by the company, and it is considered will need time to adapt, so the initial performance is not maximum (Sihombing, 2014).

\section{The Effect of Arrogance on Fraudulent Financial Reporting}

The testing result of the fifth hypothesis (H5) shows that variable arrogance with managerial shareholding $(\mathrm{OM})$ proxy does not significantly affect in detecting fraudulent financial reporting with the significance level of 0.257 and $B$ of 0.052 . This result might be because the average of managerial shareholding in the sample company is still low. The result of this study is in accordance with the study done by Tiffani and Marfuah (2015) concluding that the percentage of shareholding by inside persons does not affect fraudulent financial reporting.

\section{Conclusion and Limitation}

\section{Conclusion}

Based on the study done on 59 manufacturing companies in 2013-2015 provide pressure with proxies of financial stability (current), external pressure (Lev), and financial target (ROA), opportunity with the nature 
Business Ethics and Leadership, Volume 3, Issue 3, 2019

ISSN (online) - 2520-6311; ISSN (print) - 2520-6761

of industry (receivable) proxy, and arrogance with managerial ownership (OM) proxy does not affect fraudulent financial reporting.

Rationalization with total accruals (TAc) proxy and capability with change of directors (CoD) proxy, is proven to affect fraudulent financial reporting. Significance value that is smaller than 0.05 shows that the regression model can be used to predict Fraudulent Financial Reporting, or it can be said that all independent variables together affect dependent variables.

\section{Limitation}

This study has some limitations which are, first, this study uses manufacturing companies listed on IDX in 2013-2015 as a sample. Second, this study uses a quantitative method in the measurement and the analysis of its variables without any exception, so it is assumed that each variable obtains equal weight. Third, in this study, fraudulent financial reporting is measured with a fraud score, where it is still rarely used, so further study is needed. Fourth, variables of capability and arrogance are measured using dummy variable proxy, so the result obtained is still less accurate in detecting fraudulent financial reporting.

\section{Suggestion}

Based on the conclusions and limitations above, the writer suggests to, first, expand the research sample by using all companies listed on IDX and to add the period of observation. Second, the next study related to fraudulent financial reporting using the quantitative method can use a qualitative method because there are variables that cannot be explained specifically by a quantitative method such as the measurements of capability and arrogance that will be better to be measured with qualitative method analysis instrument. Third, the next study is expected to be able to conduct a further study by using F-score measuring instrument, but also with more searching references.

\section{References}

1. Albrecht, W. S., Albrecht, C.O., Albrecht, C.C. and Zimbelman, Mark F. (2011). Fraud Examination 4th Edition. Cengage.

2. Annisya, Mafiana, Lindrianasari, Yuztitya Asmaranti (2016). Fraudulent Detection of Financial Statements Using Diamond Fraud. Faculty of Economics and Business, University of Lampung. Journal of Business and Economics (JBE), Maret 2016, 23(1), 72-89. ISSN: 1412-3126.

3. Ardiyani, Susmita dan Utaminingsih, Nanik Sri (2015). Analisis Determinan Financial Statement Melalui Pendekatan Fraud Triangel. Accounting Analysis Journal, 4(1), 1-10.

4. Association of Certified Fraud Examiners (2016). Report to the nation on occupational fraud and abuse (2016 global fraud study).

5. Beneish, M., (1997). Detecting GAAP Violation: implications for assessing earnings management among firms with extreme financial performance. Journal of Accounting and Public Policy, 16, 271-309.

6. Crowe Horwarth (2010). IIA Practice Guide: Fraud and Internal Audit.

7. Dechow, P. M., Hutton, A. P., Kim, J. H., and Sloan, R. G. (2012). Detecting Earning Management: A New Approach. Journal of Accounting Reserach, 50(2), 275-334.

8. Dechow, P. M., Hutton, A. P., Kim, J. H., and Sloan, R. G. (2012). Consideration of Fraud in a Financial Statement Audit. (Supersedes SAS No. 82.)

9. Ghozali, Imam (2013). Aplikasi Analisis Multivariate Dengan Program SPSS 21, Edisi Ketujuh. Semarang: Badan Penerbit Universitas Diponegoro.

10.Hanifa, Septia Ismah dan Laksito, Herry (2015). The Influence of the Fraud Indicator on the Financial Statement Fraudulent: Empirical Study of Companies Listed on the Indonesia Stock Exchange (IDX) Year 2008-2013. Journal of Accounting, 04(04), 1-15.

11.Jansen, Michael C. and Meckling, William H. (1976). Theory of the Firm: Managerial Behavior, Agency Cost and Ownership Structure. Journal of Financial Economics, 3(4), 305-306.

12.Jones, Peter and Daphne Comfort (2018). Sustainable Consumption and the Leading US Retailers. Indonesian Journal of Corporate Social Responsibility and Environmental Management, 1(1), 1-15. Available at: http://ijcsrem.org/index.php/ijcsrem.

13.Karima, Naila (2014). Effects of Managerial Ownership, Institutional Ownership, and Foreign Ownership on Corporate Social Responsibility Disclosure. Widya Warta No. 02 Year XXXV III/July 2014. ISSN 0854-1981. 
14.Manurung, Daniel T. H., dan Hadian, Niki (2013). Detection Fraud of Financial Statement with Fraud Triangel. Proceedings 23rd International Business Research Conference 18-20 November 2013, Marriot Hotel, Melbourne, Australia, ISBN: 978-1-922069-36-8.

15.Munawir (2014). Analisis Laporan Keuangan [Financial Statement Analysis]. Jogjakarta, Liberty.

16.Norbarani, Listiana (2016). Detection of Financial Statement Fraud with Fraud Analysis Triangle Adopted in Sas No.99. Faculty of Economics and Diponegoro University Business Semarang.

17.Sihombing, Kennedy Samuel dan Rahardjo, Shiddiq Nur (2014). Diamond Fraud Analysis in Detecting Fraud Financial Statement: Empirical Study of Manufacturing Companies Listed on the Indonesia Stock Exchange (BEI) 2010-2012. Diponegoro Journal of Accounting, 03(02). ISSN (Online): 2337-3806.

18.Subramanyam, K.R. dan Wild, John J. (2010). Analisis Laporan Keuangan Buku1Edisi 10. Jakarta: Salemba Empat.

19.Pardosi, Rica Widia (2015). Diamond Fraud Analysis in Detecting Financial Statement Fraud in Manufacturing Companies in Indonesia Using the Fraud Score Model (Year 2010-2013). Faculty of Economics and Business. University of Lampung.

20.Rini, Viva Yustitia (2012). Analisis Prediksi Potensi Risiko Fraudulent Financial Statement Melalui Fraud Score Model [Analysis of Fraudulent Financial Statement Risk Potential Predictions Through the Fraud Score Model]. Diponegoro Journal of Accounting, 1(1), 1-15.

21.Tessa, Chyntia dan Harto, Puji (2016). Fraudulent Financial Reporting: Pengujian Teori Fraud Pentagon Pada Sektor Keuangan Dan Perbankan Di Indonesia. Semarang. Simposium Nasional Akuntansi XIX, Lampung, 2016.

22.Tiffani, Laila Dan Marfuah (2015). Deteksi Financial Statement Fraud Dengan Analisis Fraud Triangle Pada Perusahaan Manufaktur Yang Terdaftar di Bursa Efek Indonesia [Detection of Fraud Financial Statement with Fraud Triangle Analysis on Manufacturing Companies Listed on the Indonesia Stock Exchange]. JAAI, 19(2), Desember 2015: 112-125.

23.Wolfe, David T. and Hermanson, Dana R. (2004). The Fraud Diamond: Considering the Four Elements of Fraud. CPA Journal, 74(12), 1-5. 